\title{
THE LEVEL OF INTERNET ADDICTION OF STUDENTS FROM DIFFERENT BULGARIAN UNIVERSITIES
}

\author{
Milena Kuleva \\ National Sports Academy "Vassil Levski”, Sofia, Bulgaria
}

\begin{abstract}
Introduction: In this scientific study, we address the problem of Internet addiction. This is an increasingly popular topic as many studies indicate that society is becoming more dependent on the Internet.

Methodology: We used a self-assessment Internet Addiction Test (IAT), developed by Dr. Kimberly Young, and we distributed it to students from 3 universities - National Sports Academy "Vassil Levski", Veliko Turnovo University and GS Rakovski Military Academy.

Results and discussion: The results of the study showed that in all three universities, the level of internet addiction is Mild. The highest addiction is observed among students from the NSA, and the lowest among students from the Military Academy. This can be explained in the following way: the trainees at the Military Academy are mostly family type and in their social life, after completing their duties and the training is oriented to the family circle. Also, Internet usage at work is limited.

Conclusions: In this study, it became clear that lack of time to communicate and make friends "offline" is a prerequisite for higher internet addiction. We believe that internet addiction is significantly higher in all surveyed people, and the difference is determined by the fact that modern life is at extremely high speeds and the luxury of "standing at the computer" is minimized.
\end{abstract}

Key words: Internet Addiction Test, university, level of addiction

\section{INTRODUCTION}

You may not have paid attention to how often people around you look at their phones and surf the Internet or social networks. This observation raised the question whether all people are dependent and addicted to the Internet or it happens only in certain cases, or in only certain social groups or rather, not happening at all. Internet addiction was first examined in 1996, with the findings made available to the American Psychological Association (APA). Early studies have tried to determine dependence on the Internet and were examined behaviors that differ from normal compulsive use of the Internet. One of the most famous researchers in this thematic - Dr. Kimberly Young thinks that "as the problem becomes more widespread, new research looks at the neurological causes of Internet addiction and the ways in which the disorder can be cured primarily through behavioral therapy, cognitive behavioral techniques and residential care". (Montag \& Reuter, 2017)

New Internet addicts meet two different criteria. First, they become addicted to new forms of Internet use, created only online, such as chat rooms, social networks, instant messaging, online games or online shopping. Of course, these activities have already become portable through mobile devices such as iPhones, droids or iPads or mobile phones. The key element is that they are all considered to be specific to Internet activities.

Second, new Internet addicts are individuals without a previous significant history of addiction or psychiatry. They are addicted to the anonymous, accessible and interactive nature of online use. Intrusive use of the Internet is a new clinical phenomenon. (Montag \& Reuter, 2017) (Young, 2004)

\section{METHODOLOGY}

In this study we use a self-assessment questionnaire developed by Dr. Kimberly Young for of Internet addiction. (IAT) and it contains 20 questions (items). The participants were asked to consider only the time spent online for nonacademic or nonjob purposes when answering. The level of addiction is assessed with a Likert scale, containing the following options: $0=$ Not Applicable; $1=$ Rarely; 2 = Occasionally; $3=$ Frequently; $4=$ Often; $5=\mathrm{Al}$ ways. The final results are evaluated on the following scale: Normal Range: 0-30 points; Mild: 31-49 points; Moderate: 50-79 points; Severe: $80-100$ points. We added a few additional questions to the questionnaire, such as age, university, height, and 
weight (in order to compare results with body mass index of the students). The study was conducted in the period May-June 2019 and was made by students from 3 universities - National Sports Academy "Vassil Levski", Veliko Turnovo University and the Military Academy "G.S. Rakovski”. The number of surveyed students is $(\mathrm{n}=133)$, and for the purposes of our study, we make a comparison between students from the National Sports Academy and students from other universities. In addition to the analysis of the results on the proposed scale to the questionnaire, a variational and correlation analysis was made and subsequently Pearson Chi Square. For the analyzes it is used the statistical software SPSS ver. 19.

\section{RESULTS AND DISCUSSION}

According to Nakaya (2015), for some youth, going away to college and being free from parental supervision can cause them to spend large amounts of time using the Internet. College students have large blocks of free time and the ability to spend as much time as they want online without a parent reminding them to take a break or attend to other obligations. The average age of the surveyed students is 28 years, with no statistically significant differences in the gender and educational indicators in general. But when going through the items in the questionnaire and comparing the individual indicators, it was found that there was a statistically significant difference between them. In the study, the distribution is as follows - 29 women and 104 men. 65 students from NSA and 68 students from other universities (BA - 36 and VTU - 32).

The results we obtained from analyzing the data on the proposed rating scale in the internet addiction test showed that overall, internet dependency is "Mild". The breakdown by university is presented in Table 1.

Table 1. Distribution by universities

\begin{tabular}{|l|l|l|l|l|}
\hline \multicolumn{1}{|c|}{ University } & \multicolumn{1}{|c|}{ Participants } & $\begin{array}{c}\text { Mean score from } \\
\text { the test }\end{array}$ & $\begin{array}{c}\text { Minimum score } \\
\text { from the test }\end{array}$ & $\begin{array}{c}\text { Maximum score } \\
\text { from the test }\end{array}$ \\
\hline UVT & 32 & 34.7742 & 20.00 & 58.00 \\
\hline MA & 36 & 30.3056 & 20.00 & 66.00 \\
\hline NSA & 65 & 35.3846 & 20.00 & 65.00 \\
\hline TOTAL & 133 & 33.8561 & 20.00 & 66.00 \\
\hline
\end{tabular}

From the table presented, the average of all universities that took the test is almost 34 points, which according to the rating scale corresponds to a slight or weak dependence on the Internet. The highest addiction is observed among students from the NSA, and the lowest among students from the Military Academy. This can be explained in the following way: the trainees at the Military Academy are mostly family type and in their social life, after completing their duties and the training is oriented to the family circle. Also, Internet usage at work is limited. In most of the cases, the military officers as a character are introverts. They are disciplined and strictly follow the rules. (Iancheva, Kuleva, 2018). On the other hand, students from NSA also follow the rules, they are athletes, but they are more extroverted as a type of people. We explain their higher addiction with the following reasons: after completing daytime education, a large proportion of students are practicing some kind of a sport, which significantly reduces the time for communication and meeting their social needs. These students also have a lower age range than those from MA and VTU. In support of this statement is the high statistical reliability of the Pearson coefficient in the correlation of the questions is statistically significant $\left({ }^{* *} p<0.01\right.$ level (2-tailed) and it supports the statement with the following questions: How often do you lose sleep due to late-night log-ins?" and „How often do you find yourself saying "Just a few more minutes" when online?" $\left(\mathrm{r}=, 394^{\star *}\right)$, also for „How often do you form new relationships with fellow online users?" $\left(\mathrm{r}=235^{\star *}\right)$ correlated with "How often do your grades or schoolwork suffer because of the amount of time you spend online?" $\left(\mathrm{r}=246^{* *}\right)$. In the variational analysis, the values were found to be normal and close to the normal distribution, which enabled us to apply Chi Square (Pearson) for some of the questions. 
Table 2. Variational analysis of the input data of the interviewed students

\begin{tabular}{|l|l|l|l|l|l|l|l|l|l|}
\hline Indicator & \multicolumn{1}{|c|}{$\mathbf{N}$} & \multicolumn{1}{|c|}{ Min } & \multicolumn{1}{c|}{ Max } & \multicolumn{1}{c|}{ Mean } & \multicolumn{1}{c|}{$\mathbf{R}$} & \multicolumn{1}{c|}{ S } & \multicolumn{1}{c|}{ As } & \multicolumn{1}{|c|}{ Ex } & \multicolumn{1}{c|}{ V } \\
\hline Age & 133 & 19,00 & 54,00 & 28,23 & 35,00 & 9,941 & 0,825 & $-0,709$ & 35,22 \\
\hline Weight & 133 & 48,00 & 128,00 & 78,21 & 80,00 & 15,631 & 0,445 & 0,759 & 19,99 \\
\hline Hight & 133 & 158,00 & 200,00 & 178,23 & 42,00 & 9,228 & $-0,086$ & $-0,270$ & 5,18 \\
\hline BMI & 133 & 16,90 & 37,40 & 24,50 & 20,50 & 3,909 & 0,565 & 0,165 & 15,95 \\
\hline
\end{tabular}

When we look at the issues individually, we find some more dependencies.

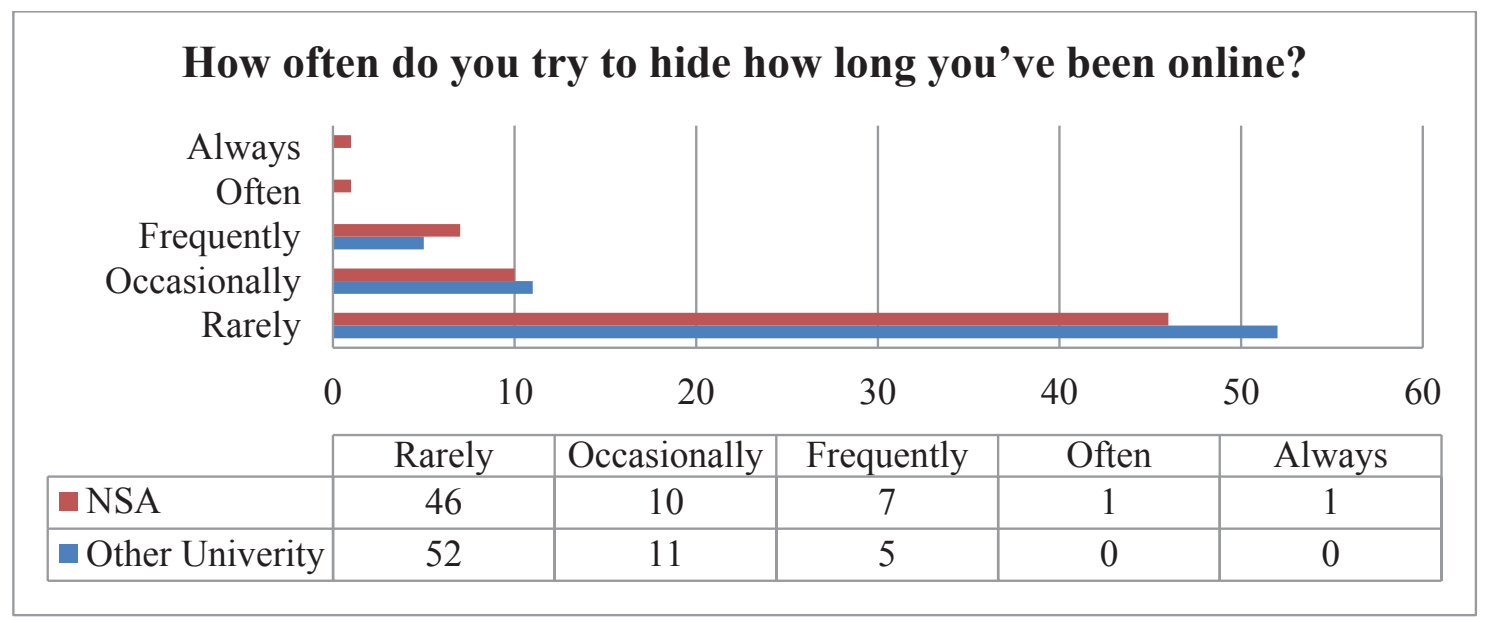

Figure 1. How often do you try to hide how long you've been online?

The results presented in Figure 1 shows that the the majority consider the internet to be a given and majority of the surveyed students do not hide their spending time online is more of a natural phenomtime spent online, which support the statement that enon. This statement is confirmed by the data prethey use the internet to meet social needs and that sented in Figure 2.

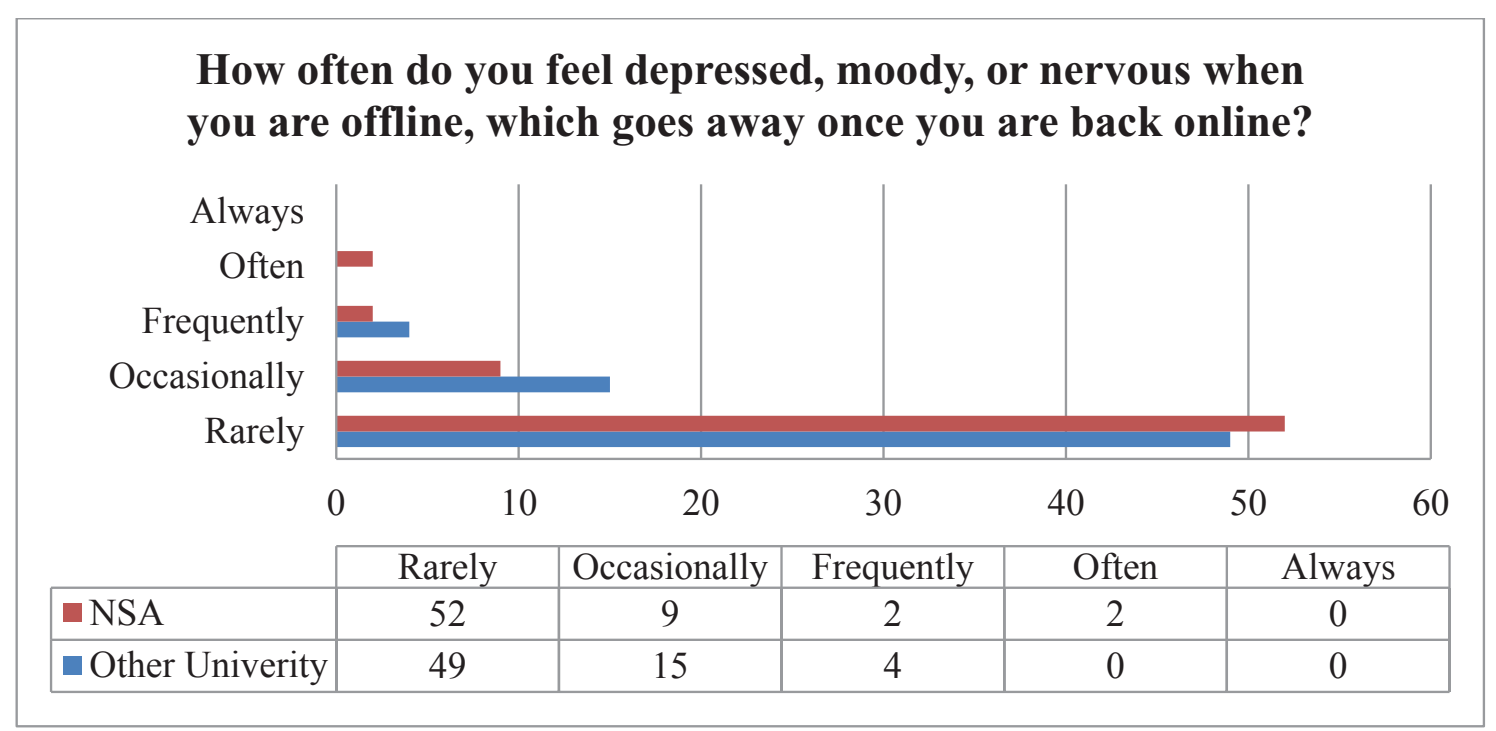

Figure 2. How often do you feel depressed, moody, or nervous when you are offline, which goes away once you are back online?

The correlation between the attempts to hide time mean that most people are aware of the harm of spent on the Internet and the desire to spend less standing in front of a computer and spending time time is also significant $\left(r=, 460^{* *}\right)$. This could on the Internet, but at the same time, these people 
feel depressed when they are not online. Similar correlation is also discussed by Leung (2007).

\section{CONCLUSION}

In this study, it became clear that lack of time to communicate and make friends "offline" is a prerequisite for higher internet addiction. We believe that internet addiction is significantly higher in all surveyed people, and the difference is determined by the fact that modern life is at extremely high speeds and the luxury of "standing at the computer" is minimized. Overall, the IAT provides a framework for assessment of specific situations or problems that have been caused by computer overuse to use in subsequent treatment planning. People use their mobile phones massively, and we believe this could be confirmed through the Mobile Phone Dependence Questionnaire (MPDQ). We believe that the research could be expanded, and the mobile addiction could be presented and examined better in the near future. This is the subject of our next study, comparing internet addiction, mobile device addiction, and physical activity of study participants.

\section{REFERENCES}

Iancheva, T. \& Kuleva, M. (2018). Tarsene na useshtania i spravyane sas stres pri uchastnitsi vav voenni misii v Afganistan, Proceeding book of the Fifth Scientific Conference "Sport and Security", 21-22 May, Sofia. // Янчева, Т. \& Кулева, М. (2018). Търсене на усещания и справяне със стрес при участници във военни мисии в Афганистан. Proceeding book of the Fifth Scientific Conference "Sport and Security", 21-22 май, София. Leung, L. (2007). Stressful life events, motives for Internet use, and social support among digital kids. Cyber Psychol Behav, pp. 204-214.

Montag, C., \& Reuter, M. (2017). Internet Addiction. Neuroscientific Approaches and Therapeutical Implications Including Smartphone Addiction. Germany: Springer.

Young, KS. (2004). Internet addiction: the consequences of a new clinical phenomena. In: Doyle K. (ed.) American behavioral scientist: psychology and the new media. Sage, Thousand Oaks, pp. 1-14

Nakaya, A. (2015). Internet and social media addiction. Reference Point Press, Inc., San Diego, CA, USA, pp.36

Corresponding author: Milena Kuleva, PhD National Sports Academy "Vassil Levski" 21 Acad. Stefan Mladenov, str. Sofia, 1000, Bulgaria E-mail:mil3na@gmail.com 